\title{
MEMBINCANG AGAMA DAN \\ NEGARA TANPA KEKERASAN GENDER
}

Nur Solihin, SAg.,MH.

Dosen Jurusan Syari'ah STAIN Jember

\begin{abstract}
Violence towards women in Indonesia which is conducted whether by individual, family, society and state (itself) is a continuing phenomenon. Various concepts on this sort of case are offered by experts, seminars, discussions to give solution. Furthermore, CEDAW (Convention on the Elimination of Discrimination Against Women) has been ratified since May, 1982 by Indonesia as legal platform to eliminate the violence. On the contrary, the state involves in several violence cases(particularly in new order era) such as the case in Aceh, East Timor, Irian Jaya and chaos in May, 1998 of which most women are the victims. Domestic violence is another feature of women's condition under the banner of state ideology and religious ideology that are supported by patriarchal system. This paper points out that democratizing country and reinterpreting religious texts (which are more gender sensitive) are the alternative solutions for aforementioned problems.
\end{abstract}

\section{A. Pendahuluan}

Masalah kekerasan gender akhir-akhir ini menunjukkan gejala yang memprihatinkan, baik dari segi kuantitas maupun kualitas sadisme yang dilakukan pelaku terhadap korban. Mulai dari kekerasan psikis, seksual dan fisik, baik di ranah domestik maupun publik. Baik itu dilakukan oleh keluarga dekat, masyarakat maupun negara.

Kekerasan negara merupakan salah satu ciri kuat dalam sejarah abad 20 sepanjang sejarah. Hingga penghujung abad ini, masih banyak hal yang tidak kita pahami, bahkan kita tidak mampu mempertanyakan mengenai seluk beluk kekerasan negara terhadap perempuan. Masih jelas terngiang dalam ingatan kita, peristiwa perkosaan Mei 1998 di Jakarta dan beberapa kota lainnya. Memang, negara bukan satu-satunya yang harus bertanggung jawab atas peristiwa itu, namun kekerasan negara menjadi salah satu faktor penyebab utama. 
Mengapa permasalahan perempuan tak kunjung mengecil? Bahkan terus mengemuka bagaikan fenomena gunung es, yang nampak di permukaan kecil tetapi sebenarnya begitu meluas. Permasalahan kekerasan terhadap perempuan terus menghampiri semua kalangan, tak pandang bulu apakah itu kalangan pinggiran atau perkotaan, kalangan miskin atau kaya, terpelajar atau tidak. Begitu kompleksnya persoalan perempuan, dimanapun dan kapanpun perempuan rentan untuk mendapatkan perlakuan diskriminasi dan tekanan, baik ekonomi, keamanan, sosial maupun poltik.

Tentu hal ini tidak bisa dibiarkan begitu saja tanpa ada sesuatu yang diperbuat, khususnya bagi para aktivis perempuan, pekerja sosial, akademisi, agamawan, dan apalagi negara.

\section{B. Negara dan Kekerasan Gender}

Negara dijabarkan sebagai suatu pesekutuan individu-individu yang dengan sukarela menyerahkan dan mempercayakan pengaturan kehidupannya ke dalam sebuah lembaga yang bernama negara. Hidup bernegara dalam bentuk yang berbeda-beda sudah lama ada pada masyarakat sederhana. Pembentukan negara ini mengalami suatu evolusi. Bentuk awal dari pranata negara adalah Tribes yaitu kelompok individu yang hidup berburu dan meramu, yang mana penyatuan mengenai hak dan kewajiban semata-mata berdasarkan perbedaan jenis kelamin dan usia. Laki-laki yang berburu, perempuan yang meramu hasil buruan. Anggota Tribe menerima pembagian kerja tersebut secara alamiah, karena dianggap tidak ada yang dirugikan dan merugikan orang lain.

Selanjutnya bentuk yang lebih maju adalah chiefdom, yang memiliki ciri sudah menyelenggarakan kegiatan pertanian dan lainnya dengan suatu spesifikasi kerja berdasarkan keahlian, dan semua proses kegiatan ekonomi dan politik berdasarkan unsur kekerabatan. Kemudian perkembangan selanjutnya adalah masyarakat berstrata yang terdesentralisasi, yang memiliki ciri tidak ada sistem 
kekerabatan. Dan pekembangan terakhir dikenal dengan bentuk negara (The State) yang ditandai dengan kuatnya birokrasi dan feodalisme. ${ }^{1}$

Sebetulnya Indonesia seperti halnya negara-negara lain juga dapat dikatakan telah melalui tahapan evolusi untuk sampai ke dalam bentuk negara Republik Indonesia. Dari fase masyarakat Tribe seperti orang-orang Kubu, Sakai sampai dengan bentuk Huta atau Nagari. Kemudian penjajah Belanda memperkenalkan suatu bentuk negara modern yang ditopang oleh birokrasi yang tangguh. Dalam tahapan evolusi tersebut sebenarnya terjadi suatu kesinambungan sistem-sistem nilai yang mengatur hubungan manusia khususnya antara laki-laki dan perempuan berdasarkan budaya lokal, namun tidak demikian halnya dengan Indonesia lebih-lebih pada masa Orde Baru.

Dengan demikian, diakui atau tidak, Indonesia masih menjalankan politik patriarkhis yang merupakan turunan dari karakteristik negara yang patriarkhis, dan negara yang mengedepankan kepentingan laki-laki. Kemudian muncul kesan kuat bahwa negara identik dengan kekerasan apalagi bila negara tersebut diatur oleh militer. Contoh yang paling nyata adalah Indonesia pada masa orde baru dapat dikatakan sebagai rezim militer. Masyarakat yang menjadi oposisi atau terlalu kritis ditahan, ditangkap, dan diculik bahkan hilang tak tentu rimbanya. Rezim militer saat itu banyak diwarnai dengan kekerasan termasuk kekerasan gender. Salah satu bentuk kekerasan tersebut adalah pemaksaan negara dalam penggunaan alat kontrasepsi sebagai program sukses BKKBN.

Bentuk kekerasan lainnya adalah penyiksaan dan penjarahan terhadap milik perempuan yang sangat berharga, mulai dari intimidasi, teror, pelecehan seksual, perkosaan sampai pembunuhan. Seperti halnya di Aceh semenjak menjadi daerah DOM merupakan salah satu pusat intimidasi dan kekerasan terhadap perempuan. Meskipun operasi militer bertujuan untuk memerangi kaum laki-laki yang dianggap berpihak pada GAM, namun acapkali terjadi perempuan dijadikan umpan oleh pihak militer untuk menangkap anggota GAM. Dan tak jarang diwarnai dengan kekerasan baik secara fisik maupun psikis.

\footnotetext{
${ }^{1}$ Nur Iman Subono (Ed), Negara dan Kekerasan Terhadap Perempuan, 2000, Jakarta, YJP,XIV.
} 
Organisasi perempuan yang bernama Flower Aceh mengungkapkan adanya pelanggaran HAM kategori berat oleh negara melalui operasi militernya. Ada sejumlah kasus perkosaan yang dilakukan tentara yang sedang bertugas. Demikian juga dengan kasus Timor Timur sejak menjadi propinsi termuda 1976, penaklukannya dilakukan dengan menzinahi perempuannya seperti layaknya yang dilakukan tentara Serbia terhadap perempuan Bosnia. Begitupun dengan kasus penganiayaan dan perkosaan yang terjadi di Irian Jaya ketika menjadi daerah operasi militer. Begitu banyak kasus yang terjadi tetapi begitu heningnya negara merespon kekejian itu, negara telah membiarkan kekerasan tejadi, bahkan dianggap bonus bagi mereka yang memenangkan pertempuran. ${ }^{2}$

Selain itu, kekerasan gender ini juga dapat dilihat pada buruh migran, pemerintah menyusun aturan dan kebijakan yang diskriminatif dan eksploitatif, serta membiarkan kekerasan terus berlangsung, dan PJTKI pun hanya mengutamakan keuntungan daripada perlindungan. Secara struktural, Depnaker ikut berperan dalam menciptakan iklim/budaya kekerasan bagi buruh migran. Hal ini dapat dilihat dari ketentuan yang dirumuskannya, antara lain jam kerja (16) jam, pelarangan bicara dengan wartawan, perumusan ikrar buruh migran pemerintah, dan lain sebagainya.

Selanjutnya setelah sampai di tempat tujuan kerja, kekerasan masih saja menghantui buruh migran, di antaranya pemerasan, penganiayaan dan perkosaan. Perkosaan merupakan bentuk kekerasan yang paripurna dari kekerasan yang dialami buruh migran. Mereka juga pasti akan mendapat bentuk-bentuk kekerasan lainnya dan menyisakan penderitaan yang dalam dan menanggung malu, dikucilkan, dihina, tidak dapat bekerja dan tekanan psikologis, bahkan masih mendapat ancaman hukuman rajam maupun pancung. Adapun tindakan preventif dari pemerintah untuk melindungi buruh migran dari kekerasan ini sangat langka, bahkan juga pada taraf kuratif dan pembelaan masih relatif kecil. ${ }^{3}$

\footnotetext{
${ }^{2}$ Negara dan Kekerasan Terhadap Perempuan, YJP, XX.

${ }^{3}$ Ibid., 226.
} 


\section{Kekerasan dalam Rumah Tangga}

Berdasarkan data sebuah penelitian, satu dari tiga orang isteri pernah mengalami KDRT, Sejumlah LSM di Jakarta menerima pengaduan sebanyak 879 kasus KDRT sepanjang tahun 1997-2002. Di Yogjakarta, Rifka Anissa menerima pengaduan sebanyak 994 kasus kekerasan dalam Rumah Tangga (KDRT)(suami terhadap isteri) sepanjang tahun 1994-2000, ia juga mencatat bahwa di Yogjakarta terjadi 415 kasus kekerasan terhadap perempuan sepanjang tahun 2002, 247 kasus, di antaranya merupakan kasus kekerasan terhadap isteri. Sementara itu di Pasuruan sejak tahun 1998-2002 telah terjadi KDRT yang berupa 55 perkosaan terhadap anak di bawah umur. Di Malang berdasarkan penelitian yang dilakukan oleh PSW UNIBRAW ditemukan bahwa pada tahun 1997 korban dari tindak kejahatan $97 \%$ adalah perempuan. Fakta tersebut cukup mengejutkan, betapa tidak, kekerasan dalam rumah tangga hampir mencapai separuh dari jumlah kehidupan pasangan suami isteri, dan angka-angka ini hanya sebagian kecil dari kasus yang ada di masyarakat, mengingat masyarakat enggan untuk melaporkannya, sehingga kasus-kasus KDRT banyak yang tidak terdeteksi.

Dalam kasus KDRT, sebenarnya pelakunya tidak selalu laki-laki dan korbanpun tidak selalu perempuan, tetapi menurut catatan WHO perempuan merupakan korban terbesar. Kebanyakan pelakunya adalah suami terhadap isteri, orang tua atau juga mertua terhadap anak/menantu, kakak terhadap adik, paman terhadap keponakan atau sebaliknya, majikan terhadap pembantu rumah tangga. KDRT ini juga terjadi tidak saja pada kelas sosial bawah tapi juga pada kelas atas. Bahkan kini sering kita jumpai, kekerasan terjadi di kalangan rumah tangga selebriti.

Pada era reformasi, ada secercah harapan baru untuk mereformasi secara menyeluruh dalam sistem politik, pemerintahan, ekonomi, dan sosial, termasuk menekan terjadinya tindak kekerasan terhadap perempuan. Dan pada tahun 2000 ada kemajuan penting yang patut dicatat, yaitu keluarnya Inpres No.9 tahun 2000. Inpres tersebut menekankan keharusan setiap instansi pemerintah untuk melakukan pengarusutamaan gender. Sekalipun hanya sebuah Inpres, suatu produk yang lemah kekuatan hukumnya dibanding Keppres apalagi UU, ini sudah 
merupakan produk yang monumental dari perjuangan perempuan yang teramat panjang, kegagalan pembuatan Keppres saat itu tidak terlepas dari sikap setengah hati para politisi dan sejumlah tokoh kunci di pemerintahan. Begitupun dengan UU KDRT NO. 23/2004, merupakan hasil perjuangan panjang yang teramat melelahkan, sekalipun masih perlu penyempurnaan.

\section{Kekerasan Gender dan Penyebabnya}

Kekerasan gender merupakan perwujudan kerentanan perempuan di hadapan laki-laki, karena perempuan dianggap lemah. Kekerasan terhadap perempuan bukan lagi masalah individu, tetapi merupakan persoalan sosial yang berkaitan dengan segala bentuk kekerasan, kekejaman dan pengabaian terhadap martabat manusia. Kekerasan terhadap perempuan bukan saja dapat melemahkan perempuan tetapi juga dapat mematahkan semangat dan bahkan membunuh perempuan.

Sebenarnya, bagaimanakah rumusan kekerasan gender itu sendiri? Jika kita kaji lebih jauh, ternyata rumusan kekerasan tidak pernah berhenti tetapi terus berkembang, kalau menurut Gelles dan Staruss kekerasan adalah an act carried out with the intention or perceived intention of physically hurting another person. Schuler menambahkan jika berbicara kekerasan gender maka tinggal menambahkan aspek gender pada definisi ini. ${ }^{4}$ Konferensi perempuan sedunia di Beijing tahun 1995, memeperluas kekerasan gender dengan "Tindakan kekerasan apapun yang dilakukan berdasarkan gender dan mengakibatkan atau dapat mengakibatkan bahaya fisik, seksual, psikologis terhadap perempuan atau penderitaan perempuan termasuk ancaman, paksaan atau perampasan kemerdekaan secara sewenang-wenang baik dalam kehidupan publik maupun pribadi”. Rumusan ini jelas lebih luas, tidak saja terbatas pada kekerasan fisik seperti rumusan Gelles tetapi juga seksual dan psikologis.

Dalam UU tentang KDRT NO. 23/2004 pasal (1) disebutkan "Kekerasan dalam rumah tangga adalah setiap perbuatan terhadap seorang perempuan, yang berakibat timbulnya kesengsaraan atau penderitaan secara fisik, seksual,

${ }^{4}$ Margaret Schuler, (Ed), Freedom from Violence, New York, Unifem, 1992. 
psikologis, dan/atau penelantaran rumah tangga termasuk ancaman untuk melakukan perbuatan, pemaksaan, atau perampasan kemerdekaan secara melawan hukum dalam lingkup rumah tangga". Dengan demikian kekerasan dalam rumah tangga berupa hal-hal yang bersifat fisik, psikis, seksual, dan penelantaran rumah tangga.

Kekerasan fisik adalah perbuatan yang mengakibatkan rasa sakit, jatuh sakit, dan luka berat, sedangkan kekerasan psikis adalah perbuatan yang mengakibatkan ketakutan, hilangnya rasa percaya diri, hilangnya kemampuan untuk bertindak, rasa tidak berdaya, penderitaan psikis berat pada seseorang. Adapun yang dimaksud kekerasan seksual adalah pemaksaan hubungan seksual yang dilakukan terhadap orang yang menetap dalam lingkup rumah tangga tersebut atau salah seorang dalam lingkup rumah tangganya dengan orang lain untuk tujuan komersial.

Jika ditelisik lebih jauh maka kekerasan terhadap perempuan ini dapat dipetakan sebagai berikut:

Pelaku \& Bentuk-Bentuk Kekerasan terhadap Perempuan

\begin{tabular}{|c|c|c|}
\hline KELUARGA & MASYARAKAT & NEGARA \\
\hline $\begin{array}{l}\text { 1. Penyerangan fisik : } \\
\text { - Pembunuhan } \\
\text { - Penganiayaan } \\
\text { - Penyunatan } \\
\text { - Pengendalian alat } \\
\text { reproduksi } \\
\text { - Pembunuhan } \\
\text { terhadap } \\
\text { perempuan. } \\
\text { 2. Penganiayaan seksual: } \\
\text { - Perkosaan } \\
\text { - Incest (Hubungan } \\
\text { seks sedarah) } \\
\text { 3. Kekerasan Psikologis } \\
\text { - Pemaksaan } \\
\text { kehendak, ancaman, } \\
\text { tekanan, } \\
\text { - Kawin paksa } \\
\text { - Pengurungan }\end{array}$ & $\begin{array}{l}\text { 1.Adat \& tradisi: } \\
\text { - Indoktrinasi } \\
\text { - Kekerasan fisik } \\
\text { - Penganiayaan } \\
\text { - Hukuman fisik } \\
\text { - Pengendalian tehadap } \\
\text { alat reproduksi } \\
\text { - Sati (pembakaran diri } \\
\text { jika suami meninggal) } \\
\text { - Perkosaan } \\
\text { 2.Di tempat kerja } \\
\text { - Pelecehan seksual } \\
\text { - Intimidasi seksual } \\
\text { - Traficking } \\
\text { - Pelacuran paksa } \\
\text { - Pembedaan upah } \\
\text { 3.Media masa: } \\
\text { - Pornografi } \\
\text { - Komersialisasi tubuh } \\
\quad \text { perempuan }\end{array}$ & $\begin{array}{l}\text { 1.Kekerasan politik } \\
\text { (Kebijakan negara, } \\
\text { UU, dll) al : } \\
\text { - Diskriminasi } \\
\text { gender seperti } \\
\text { pengangkatan } \\
\text { pejabat, quota } \\
\text { politik } \\
\text { - Penahanan tidak } \\
\text { sah } \\
\text { - Sterilisasi } \\
\text { (Pemandulan) } \\
\text { - Kehamilan paksa } \\
\text { - Kekerasan pada } \\
\text { perempuan } \\
\text { dibiarkan. yang } \\
\text { 2.Kekerasan } \\
\text { tahanan : dalam } \\
\text { - Perkosaan } \\
\text { - Penyiksaan }\end{array}$ \\
\hline
\end{tabular}


\begin{tabular}{l|l|l|} 
- Poligami & \\
Pertanyaan besar yang muncul adalah mengapa perempuan begitu rentan
\end{tabular} menjadi obyek kekerasan? Menurut penulis, banyak hal yang menjadi penyebabnya, Pertama, kekerasan yang dilakukan laki-laki terhadap perempuan tersebut bermula dari sistem gender yang lebih dikenal dengan patriarkhi, yang tidak hanya menjadikan perempuan sebagai obyek yang dirugikan tetapi juga menjadikan perempuan itu sendiri belajar untuk menjadi lemah dan tidak berdaya. Selama patriarkhis disepakati sebagai suatu keniscayaan, selama itu pula kekerasan terhadap perempuan akan terus berlangsung. Sejatinya, idiologi patriarkhis bukanlah suatu monster yang membatu dan abadi, ia akan hilang jika tidak mendapat afirmasi pada tingkat praksis dari masyarakat. Begitupun dalam rumah tangga, apabila perkawinan disepakati sebagai legitimasi formal kekuasaan laki-laki terhadap perempuan, maka laki-laki berhak melakukan apapun yang dikehendaki, termasuk pemukulan dan pemaksaan seksual.

Kedua, lemahnya kontrol sosial. Jika kita telusuri lebih jauh, sistem hukum di kebanyakan negara masih bersifat patriarkal, yaitu sangat menguntungkan laki-laki, seperti Undang-undang yang mengatur keluarga, pernikahan, dan kewarisan. Di Asia Selatan, setiap hukum menjadikan laki-laki sebagai kepala rumah tangga dan pewaris utama, tidak terkecuali juga di Indonesia. UU Perkawinan No 1/1974 dinilai banyak kalangan masih bias gender, karena masih kental dengan pemihakan terhadap kaum laki-laki. Misalnya diperbolehkannya poligami (pasal 3) dengan syarat adanya persetujuan isteri, jika isteri tidak mungkin dimintai persetujuan maka tidak diperlukan persetujuan isteri (pasal 5;2). Dengan diperbolehkannya poligami tersebut, akan memunculkan kekerasan psikis terhadap isteri atau bahkan juga anak. Demikian juga dengan pasal $(31 ; 3)$ "suami adalah kepala rumah tangga dan isteri ibu rumah tangga", dan pasal $(34 ; 2)$ yang berbunyi "isteri wajib mengatur urusan rumah tangga sebaik-baiknya". Adanya pembagian peran domistik-publik tersebut akan melahirkan dampak dominasi ataupun diskriminasi dari suami terhadap isteri, dan dalam banyak kasus sering menyebabkan kekerasan terhadap isteri. Sehingga, kalaupun isteri harus bekerja mencari nafkah maka ia masih mempunyai tugas 
ganda yakni tugas domestik. Wahbah Zuhaili mengistilahkan perempuan itu mengais rezeki dengan tangan kanannya dan mengguncang ayunan dengan tangan kirinya. Maka yang harus dipikir adalah bukankah suami dan isteri dapat saling membantu? kenapa tidak berbagi peran saja?

Ketiga, ketidakseimbangan relasi antara laki-laki dan perempuan. Keempat, pembawaan diri seorang laki-laki, seperti pemabuk, berkepribadian ekstrim, kelainan seksual dan lain sebagainya, sehingga isteri dan keluarga yang berada di dalam rumah tangga menjadi orang pertama yang menjadi sasarannya. Kelima,lingkungan rumah tangga yang kurang baik, sehingga menyebabkan pribadi yang bermoral rancu. Keenam, ketergantungan ekonomi dari perempuan terhadap laki-laki, sehingga memaksa perempuan untuk menerima penganiayaan dari orang pada siapa ia bergantung.

Masih ada lagi faktor lain yang menyebabkan kekerasan gender, yaitu dalam konteks ideologi agama. Perempuan seringkali ragu untuk melawan ketidak adilan, baik yang dilakukan oleh masyarakat maupun suaminya sendiri karena doktrin dan pemikiran agama yang dianggap sakral dan tidak boleh dilawan. Keraguan itu muncul akibat banyaknya doktrin yang sebenarnya bersifat spikulatif, namun cukup banyak membuat perempuan tunduk dan pasrah. Hal ini juga diungkap dalam seminar Internasional tentang Islam, Feminism and Women's Right di Leiden awal Nopember 2001, bahwa di beberapa belahan dunia, perempuan muslimah juga mengalami perlakuan yang sama (ketertindasan dan kekerasan) yang disebabkan oleh cara pandang pemikir agama yang bias gender.

Adapun hukuman suami maupun isteri yang melakukan kekerasan terhadap pasangannya sendiri, akan dikenakan sanksi pidana. Dalam UU KDRT NO. 23/2004 disebutkan, Setiap orang yang melakukan kekerasan fisik dalam lingkup rumah tangganya, akan dipidana penjara paling lama 5 tahun, jika sampai jatuh sakit maka dipidana penjara 10 tahun, jika sampai mati, dipenjara 15 tahun, jika dilakukan oleh suami pada isteri yang tidak menimbulkan bekas penyakit maka dipenjara paling lama 4 bulan, begitu juga jika melakukan kekerasan psikis, 
dan akan dipenjara paling lama 12 tahun jika melakukan kekerasan seksual dalam rumah tangganya.

Pasal-pasal yang ada dalam UU KDRT tersebut telah memberi peluang untuk dapat menciptakan hukum yang lebih berkeadilan gender, karena UU ini secara keseluruhan mengedepankan pola relasi kemanusiaan dan kebersamaan antara suami isteri, bahwa suami isteri tidak boleh saling menyakiti dan melakukan tindak kekerasan baik fisik, psikis, seksual dan penelantaran rumah tangga.

Sayangnya, KDRT seringkali tidak terdeteksi dan penyelesaian hukumnya tidak tuntas, hal ini disebabkan pihak yang berwenang kurang mensosialisasikan UU KDRT dan kaum perempuan enggan memperkarakan penganiayaan atas dirinya. Mereka enggan melapor karena takut jiwanya terancam, atau takut kehilangan nafkah dari suami, atau takut mencemarkan nama baik dan merasa malu jika diketahui umum mengingat masyarakat masih mengganggap persoalan tersebut merupakan aib keluarga yang harus ditutupi.

\section{E. Negara tanpa Kekerasan}

Dalam perspektif negara, masalah dasar yang perlu segera dibenahi dalam rangka menekan bentuk kekerasan gender adalah menyangkut ideologi negara yang patriarkhi. Negara yang memiliki peran melindungi warganya harus mampu dan mau melakukan kepemihakannya. Negara harus memposisikan perempuan dan memberikan peluang yang sama (tidak dibedakan dengan kaum laki-laki), misalnya dalam ruang publik/ politik. Sampai saat ini masih ada image dari sebagian besar komunitas laki-laki kita, bahwa perempuan masih berperan di balik laki-laki (subordinate). Oleh sebab itu, ada sebuah keyakinan yang harus dibangun bahwa kekerasan terhadap perempuan akan berhenti di saat patriarkhi mati.

Selanjutnya, ada sebuah keniscayaan untuk membangun negara demokratis. Adapun karakteristik negara demokratis adalah sebuah negara yang responsif terhadap keinginan warga negaranya dan dapat bertindak secara efektif 
terhadap tuntutan warga negaranya. ${ }^{5}$ Warga Negara harus diredefinisi dan dipertegas bahwa perempuan adalah warga negara yang harus melancarkan tuntutannya terhadap negara. Oleh sebab itu perempuan harus mengartikulasikan tuntutannya dan mengawasi negara dalam menjalankan tuntutan tersebut

Lain dari pada itu, keberlangsungan negara demokratis yang anti kekerasan khususnya kekerasan gender, dapat dilihat dengan terakomodasinya kepentingan perempuan melalui kebijakan negara dalam lingkup publik. Negara yang masih melibatkan militer dalam kancah politik merupakan penghalang utama bagi warga negara dalam memiliki haknya terbebas dari kekerasan. Kekerasan tidak akan menyelesaikan masalah tetapi akan menimbulkan percikan-percikan masalah baru yang lebih dahsyat. Pemberdayaan perempuan dapat berjalan melalui keberadaan perempuan dalam lingkup publik baik dalam bidang ekonomi, politik, eksekutif, legislatif, dan yudikatif.

\section{F. Agama Ramah Perempuan}

Dalam perspektif agama, masalah yang perlu segera dibenahi dalam rangka menekan bentuk kekerasan gender adalah pemahaman terhadap teks-teks keagamaan. Perlu adanya rekonstruksi pemahaman agama secara tepat dan berkeadilan, melalui interpretasi teks, sejalan dengan kemaslahatan umat (baca: kontekstualisasi ajaran).

Visi Islam adalah rahmatan lil'alamin, sedangkan misi Islam: Membebaskan manusia dari penindasan, diskriminasi dan penghambaan manusia selain pada Allah SWT. Pandangan Islam terhadap perempuan adalah sama dengan pandangannya terhadap laki-laki dilihat dari segi kemanusiaanya. Hadist Nabi: Innama ar-Rijal Syaqaiqu al-Rijal

Islam melarang kekerasan terhadap perempuan, baik secara ekonomi maupun seksual, hal ini tercantum dalam surat an-nur yang artinya ${ }^{6}$ :

Dan orang-orang yang tidak mampu kawin hendaklah menjaga kesucian (diri)nya, sehingga Allah memampukan mereka dengan karunia-Nya. dan budak-budak yang kamu miliki yang memginginkan perjanjian, hendaklah

\footnotetext{
${ }^{5}$ Robert Putnam, Making Democracy Work, New Jersey,Princeton University Press, 1993, 63.

${ }^{6}$ QS.an-Nur,24;33
} 
kamu buat Perjanjian dengan mereka, jika kamu mengetahui ada kebaikan pada mereka, dan berikanlah kepada mereka sebahagian dari harta Allah yang dikaruniakan-Nya kepadamu. dan janganlah kamu paksa budakbudak wanitamu untuk melakukan pelacuran, sedang mereka sendiri mengingini kesucian, karena kamu hendak mencari Keuntungan duniawi. dan Barangsiapa yang memaksa mereka, Maka Sesungguhnya Allah adalah Maha Pengampun lagi Maha Penyayang (kepada mereka) sesudah mereka dipaksa itu.

Dalam ayat tersebut diperintahkan memberikan hak ekonomi pada yang seharusnya berhak menerima, tidak boleh mengurangi sedikitpun apalagi mengambilnya. Gambaran al-Quran itu sampai kini masih sering dan banyak terjadi, seorang isteri menjadi TKW di luar negeri dan hasil keringatnya dinikmati dan dihabiskan oeh suami di rumah. Juga sering kali terjadi seorang isteri tidak diberi nafkah sebagaimana mestinya. Ayat itu juga melarang menjerumuskan seorang budak perempuan untuk menjadi pelacur, budak saja tidak diperbolehkan apalagi perempuan merdeka. Karena hal itu merupakan bentuk kekerasan terhadap perempuan. Begitu pula dalam surat An-Nisa'(4:19) dilarang melakukan kekerasan terhadap Isteri baik secara fisik maupun psichis.

Hai orang-orang yang beriman, tidak halal bagi kamu mempusakai wanita dengan jalan paksa, dan janganlah kamu menyusahkan mereka karena hendak mengambil kembali sebagian dari apa yang telah kamu berikan kepadanya, terkecuali bila mereka melakukan pekerjaan keji yang nyata. dan bergaullah dengan mereka secara patut. kemudian bila kamu tidak menyukai mereka, (maka bersabarlah) karena mungkin kamu tidak menyukai sesuatu, Padahal Allah menjadikan padanya kebaikan yang banyak.

Ayat ini tidak berarti dibolehkan mewariskan wanita tidak dengan jalan paksa. menurut adat sebahagian Arab Jahiliyah apabila seorang meninggal dunia, Maka anaknya yang tertua atau anggota keluarganya yang lain mewarisi jandanya. Janda tersebut boleh dikawini sendiri atau dikawinkan dengan orang lain yang maharnya diambil oleh pewaris atau tidak dibolehkan kawin lagi. Pesan ayat ini adalah larangan melakukan pemaksaan dalam bentuk apapun dan membuat susah 
perempuan, karena hal itu dapat menyebabkan tekanan psichis. Bahkan diwajibkan bergaul dengan perempuan dengan cara yang baik.

Nabi juga melarang suami melakukan kekerasan fisik atau memukul isterinya $^{7}$ :

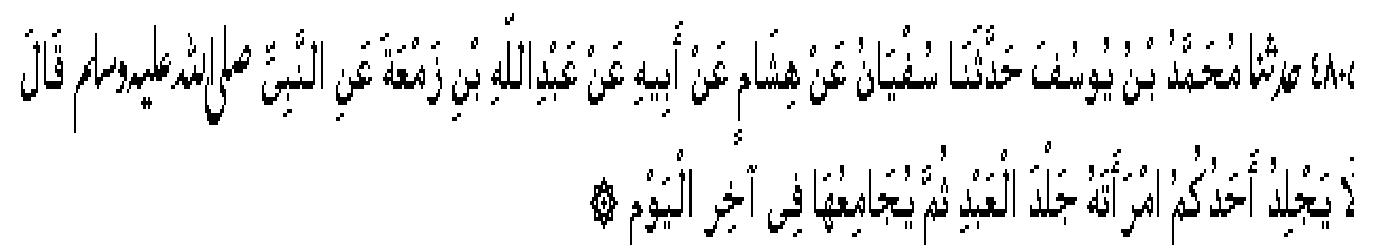

Nabi bersabda : Janganlah kalian memukul isterimu, padahal kalian menggaulinya di malam hari.

Dari sedikit contoh teks tersebut di atas dapat disimpulkan bahwa ajaran Islam itu sesungguhnya sangat netral, universal, dan ramah perempuan. Memang, secara normatis doktriner, terdapat teks-teks keagamaan (al-Qur'an-Hadits), yang jika dipahami secara literal akan memberi kesan adanya ketidaksejajaran (superioritas-inferioritas) antara laki-laki dan perempuan. Teks-teks keagamaan dimaksud di antaranya adalah yang berbicara tentang proses penciptan perempuan, kepemimpinan laki-laki atas perempuan, hak-hak reproduksi perempuan, hak kewarisan dan persaksian perempuan dan sebagainya.

Oleh sebab itu diperlukan adanya pemahaman teks agama secara komprehensif dan kontekstual, sehingga Islam betul-betul menjadi rahmatan lilalamin, kitab suci al-Quran menjadi hudan linnas, dan Nabi Muhammad menjadi uswatun hasanah atau suri tauladan dalam kehidupan sehari-hari. Keteladanan Nabi, harus diikuti secara keseluruhan apabila dalam ibadah murni, selebihnya adakalanya nilai-nilainya saja. Di sinilah peran agamawan diperlukan untuk mampu mengeksplore semangat atau nilai-nilai yang diamanatkan Nabi, dan mampu memilah sunnah Nabi sesuai konteksnya, kapan Nabi sebagai Rasul bagi seluruh ummatnya, sebagai pribadi, hakim, pemimpin, dan mufti pada zamannya.

${ }^{7}$ Sunan Ibnu Majah, hadits nomor 4805, Hadits Syarif Digital. 


\section{G. Upaya Simultan}

Jika menengok fenomena kekerasan gender ini, lantas apa yang dapat dilakukan oleh negara dan pihak-pihak yang mengatasnamakan dirinya sebagai pejuang perempuan? Menurut hemat penulis, diperlukan upaya-upaya simultan, artinya pada waktu yang bersamaan antara negara, LSM, aktivis perempuan, akademisi, agamawan, dan masyarakat secara berbarengan mencegah atau mengurangi secara bertahap persoalan kekerasan ini. Upaya-upaya tersebut dapat berupa banyak hal, antara lain; Pertama, memahami kembali teks agama yang sering dipergunakan sebagai alat untuk melegitimasi kekerasan dengan melakukan pendekatan emansipatoris. Dengan bahasa agama diharapkan dapat dijadikan sebagai entry point guna membicarakan setiap persoalan. Kedua, sosialisasi kesetaraan dan keadilan gender dengan prinsip muasyarah bilma'ruf. Ketiga, sosialisai UU KDRT. Keempat, memberdayakan ekonomi dan pendidikan perempuan, dan tentu ini memerlukan waktu yang amat panjang tetapi harus dimulai dan dilaksanakan dari sekarang. Kelima, adanya pendidikan publik agar masyarakat menyadari akan hak-hak dan kewajiban perempuan dalam masyarakat. Keenam, memberdayakan organisasi-organisasi atau LSM untuk lebih mempedulikan masalah tindak kekerasan gender. Ketujuh, membentuk lembaga konseling dan jika memungkinkan dilengkapi dengan shelter. Kedelapan, amandemen pasal-pasal dalam UU yang dirasa kurang berkeadilan gender.

\section{H. Penutup}

Dengan demikian, untuk dapat keluar dari siklus kekerasan gender ini, ada dua front yang harus dihadapi, yaitu front praktek sosial-budaya yang beridiologi patriarkhi dan front dalam konteks ideologi agama. Memang, kekerasan gender merupakan sebuah siklus yang tidak akan pernah hilang dari muka bumi, akan tetapi hal ini tidak berarti frekuensi dan prevalensi tindak kekerasan gender tidak dapat direduksi. Kini, dengan lahirnya UU KDRT berarti hukum telah memberi ruang yang memadai agar terhindar dari KDRT, dan selanjutnya berpulang pada 
masyarakat itu sendiri, karena tanpa ada partisipasi publik maka tidak akan pernah ada perubahan. 


\section{BIBLIOGRAFI}

Majah, Sunan Ibnu. Hadits nomor 4805, Hadits Syarif Digital

Putnam,Robert. Making Democracy Work, New Jersey,Princeton University Press, 1993, 63.

Schuler, Margaret (Ed),Freedom from Violence, New York, Unifem, 1992.

Subono, Nur Iman (Ed), Negara dan Kekerasan Terhadap Perempuan, Jakarta, YJP, 2000. 